\title{
Influence of discharge on fish habitat suitability curves in mountain watercourses in IFIM methodology
}

\author{
Viliam Macura ${ }^{1}$, Zuzana Štefunková ${ }^{2}$, Martina Majorošová $^{1}$, Peter Halaj $^{3}$, Andrej Škrinár ${ }^{*}$ \\ ${ }^{1}$ Department of Land and Water Resources Management, Faculty of Civil Engineering, Slovak University of Technology in Bratislava, \\ Bratislava, Slovakia. \\ ${ }^{2}$ Department of Hydraulic Engineering, Faculty of Civil Engineering, Slovak University of Technology in Bratislava, Bratislava, Slovakia \\ ${ }^{3}$ Department of Landscape Engineering, Faculty of Horticulture and Landscape Engineering, Slovak University of Agriculture in Nitra, \\ Nitra, Slovakia. \\ *Corresponding author. E-mail: andrej.skrinar@stuba.sk
}

\begin{abstract}
In this study, the quality of the aquatic habitats of mountain and piedmont streams was evaluated using the 'Instream Flow Incremental Methodology (IFIM)' decision-making tool. The quality of habitats was interpreted from the behaviour of bioindicators in the form of habitat suitability curves (HSCs). From 1995 until the present, 59 different reaches of 43 mountain streams in Slovakia and 3 validation reaches were evaluated, and the results analysed. The aim of this study was to generalize the parameters of the HSCs for the brown trout. The generalized curves will be useful for water management planning. It is difficult and time-consuming to take hydrometrical and ichthyological measurements at different water levels. Therefore, we developed a methodology for modifying suitability curves based on an ichthyological survey during a low flow and a flow at which fish lose the ability to resist the flow velocity. The study provides the information how such curves can be modified for a wider flow range. In summary, this study shows that generalized HSCs provide representative data that can be used to support both the design of river restoration and the assessment of the impacts of the water use or of climate change on stream habitat quality.
\end{abstract}

Keywords: Instream Flow Incremental Methodology (IFIM); Weighted Usable Area (WUA); Habitat suitability curves (HSCs); Brown trout.

\section{INTRODUCTION}

River regulation changes the basic morphology and flow characteristics of a river by, for example, removing the alternating of riffle zones with calm pool areas, as well as destroying the variable riparian borders and a wide range of cover places for fish. This type of activity has a negative impact on the biota of rivers, and typically results in decreased biodiversity (Cianfrani et al., 2009; Palmer et al., 2010). The negative impacts are further exacerbated by intense climate change (Van Loon et al., 2015), mainly by intense droughts during the summer seasons (Macura et al., 2016).

Modifications that result from river regulation are very noticeable in assessments of the availability of specific habitats that are needed for river restoration (Sullivan et al., 2006). It has been shown that the negative impacts of river regulation are mainly restricted to the upper reaches or rhithral of streams. The variability of the riverbed morphology decreases in the upper part of a stream, which has a significant impact on the ichthyofauna. Hence, any morphological changes are reflected by fish (Macura et al., 2012). The Water Framework Directive 2000/60/EU (2000) requires information about morphological changes and other quality characteristics of a stream that influence the presence of bioindicators including fish, diatoms, macrophytes, macroinvertebrates and similar organisms (Artemiadou and Lazaridou, 2005; Friberg et al., 2005).

A river restoration scheme that preserves the high variability of a riverbed does not have a negative impact on the overall ecosystem. The design parameters of covers, pools, and other structures that create a variable morphology in a regulated channel are therefore an important component of river restoration proposals (Pekárik et al., 2012). Biological and hydrological relationships have been studied in many streams, and authors have drawn attention to specific flow patterns that are particular to individual regions. These relationships, however, are better described by biological responses to alterations in flow regimes (Kändler and Seidler, 2013; Snelder and Lamouroux, 2010).

Lengthy discussions are ongoing among water managers, ichthyologists, and hydrobiologists (Lichner et al., 2014). At present, these specialists believe that the success or failure of any restoration project will depend on ongoing stream monitoring. Therefore, the aim of current research is to quantify the design characteristics of suitable habitats for river restoration (Döll and Zhang, 2010; Hatten et al., 2013; Pastuchová et al., 2010).

Considerable attention has been paid to the impact of climate on flow regimes (Filipe et al., 2013) and aquatic ecosystems (Fung et al., 2013), and on the protraction of dry seasons (Krysanova et al., 2010). IFIM, which is based on bioindicators, can be used to model the quality of a habitat in such studies.

When we initiated this stage of our research, we studied macrozoobenthos along with the ichthyofauna. Invertebrates respond to changes in flow and hydraulic changes (Mérigoux et al., 2009) but are less sensitive to morphological changes in regulated mountain streams (Holčík and Macura, 2001). Fish, however, are sensitive to morphological changes (Aparicio et al., 2011; Slavík et al., 2005). Furthermore, fish along with invertebrates are also sensitive to changes in water temperature, discharge (Lamouroux et al., 2006), and the quality of riparian vegetation (Džubáková et al., 2015).

\section{MATERIALS AND METHODS}

The quality of the aquatic habitats of mountain and piedmont streams was evaluated using the 'Instream Flow Incremental Methodology (IFIM)' decision-making tool. IFIM is based on 
the knowledge that most fish species prefer certain combinations of water depths, flow velocities (Ayllón et al., 2010), availability of cover, and bed materials (Parasiewicz and Walker, 2007). IFIM can provide robust assessments of the quality of a river when sufficient data are available (Casper et al., 2011). One of the greatest advantages of IFIM over alternative methods (CCA, RDA, GLM and related-analyses) is the fact that it incorporates spatially distributed model in any desired detail. In the IFIM methodology the relationship between abiotic and biotic characteristics is represented by the HSCs of various species, which are multiparametric. The curves for flow velocity and water depth are the most widely used expressions of habitat preferences by particular fish species. The preferred technique of determining values on the vertical axis between 0.0 (avoided habitat) and 1.0 (most preferred habitat) is to fit a curve to a frequency distribution of empirically-derived data.

The summer period is confining for ichthyofauna because of the low water depths, limited refuge possibilities, and low oxygen content of overheated water. The main purpose of this study was to establish the standard HSCs ranging from low flows to flows at which the fish were washed out from preferred microhabitats. These curves give better picture of the real fish habitat preference and are more suitable for designing a river restoration scheme or to support a minimum flow assessment (Harby et al., 2007). The methodology for creating HSCs that represent a wider range of flow rates is presented in this contribution.

An understanding of the influence of various parameters on the shape of the HSCs was essential, so that this information could be applied to other similar flows. The process for developing the curves involved the following steps:

- reference reaches of the streams were selected;

- an ichthyological survey and hydrometric measurements were carried out;

- topographical measurements were made of the reference reaches;

- the probability distribution functions and return period curves of flows in the reference reaches of the streams were evaluated;

- the impact of velocity and water depths on the suitability rating of a habitat were evaluated;

- the HSCs were generalized, and

- the weighted usable area (WUA) was evaluated.

These steps are further described in following section:

\section{Selection of the reference reaches of streams}

From 1995 until the present, 59 different reaches of 43 mountain streams in Slovakia and 3 validation reaches have been evaluated. In this study, we focused on smaller mountain and piedmont streams (Fig. 1) for the following reasons:

- Mountain streams have more characteristics in common, and they have been badly managed in many areas. Because of the common characteristics of mountain streams, we can expect that the results from different streams will be similar.

- Mountain streams are found in the upper reaches of a river basin. They are generally difficult to access and therefore the pollution is uncommon. The water quality therefore generally reflects the impacts of the restoration on the flow and its surroundings.

- River regulation mainly affects the morphology of the riverbed. In order to distinguish the impact of the river morphology on the quality of the aquatic habitat, only streams with good water quality have been selected. In case of poor water quality it is difficult to distinguish the impact of morphology on habitat.

- The study was focused on the upper reaches of a stream (rhithral) mainly due to the following reasons: The regulation of mountain streams aimed to flood protection significantly changes the topography of the riverbed. Regulated channels are wide and there are small water depths during low flows. This is not a suitable habitat for fish. Furthermore, mountain streams have smaller basins and are mostly not affected by pollution, thus having a good water quality. The upper reaches are therefore more sensitive to changes in flow and morphology. In this study we determined the composition of the biotic trophic groups and their production.

- When using bioindicators and IFIM to research the quality of an aquatic habitat, we assume that extreme loads of river biota also affect its overall condition. Summer low flows are considered as an extreme period. Fish are the most sensitive bioindicator of morphological changes. The responses of the bioindicators are demonstrated through the suitability curves in IFIM. The specification of the HSCs, which represent the biota of the river, is therefore an important factor in IFIM.

- The correlation between the suitability curve parameters for the depths and the hydraulic characteristics of a river has been confirmed in our previous studies (Macura et al., 2016). Therefore, we assume that the HSCs can be generalized for certain areas with different flow depths.

- Evaluations of the impact of riverbed morphology on individual fish species show that the brown trout (Salmo trutta $\mathrm{m}$. fario) is the most sensitive bioindicator of mountain streams (Macura et al., 2012). The trout is the only useful indicator in small Slovak streams and is therefore the primary target species; it was also the target species in studies of Danish streams according to Friberg et al. (2005). Therefore, we decided to focus on generalizing the HSCs for the brown trout.

\section{Ichthyological survey and hydrometric measurements}

This study was undertaken with the approval of the Ministry of Environment of the Slovak Republic. All the fish samples collected by electrofishing were immediately counted, weighted, measured and returned unharmed back to original locality in the riverbed. Authors declare that all customary standards concerning handling the live material applicable in the EU were complied.

Our ichthyological survey of selected reaches focused on determining the HSCs of individual fish species. It is important to remember that the HSCs were derived for an adult trout, because the juvenile species prefer other habitats, and would have influenced the shape of the curves (Ayllón et al., 2012). There is a similar effect from the body size of a brown trout (Ayllón et al., 2009; Parra et al., 2011). Data were obtained by electro fishing, as in Lamouroux et al. (1998). The fish were collected by an electrical aggregate with a continuous choice of electrical parameters (Hans Grassl-ELT62IIHI). The parameters of the electrical current of the aggregate were determined by the water conductivity and were also based on the fish species and their sensitivity to an electrical current, as reported in (Scholten, 2003). The flow depth, the characteristics of the microhabitat, and the velocity were surveyed at the sites where the fish were captured. The velocity was measured by a set of three hydrometric rod-mounted propellers at standard water depths (D) of $0.2 \mathrm{D}, 0.4 \mathrm{D}$, and $0.8 \mathrm{D}$. The mean velocity in vertical derived from these measurements was used to evaluate the HSC for the velocity. 


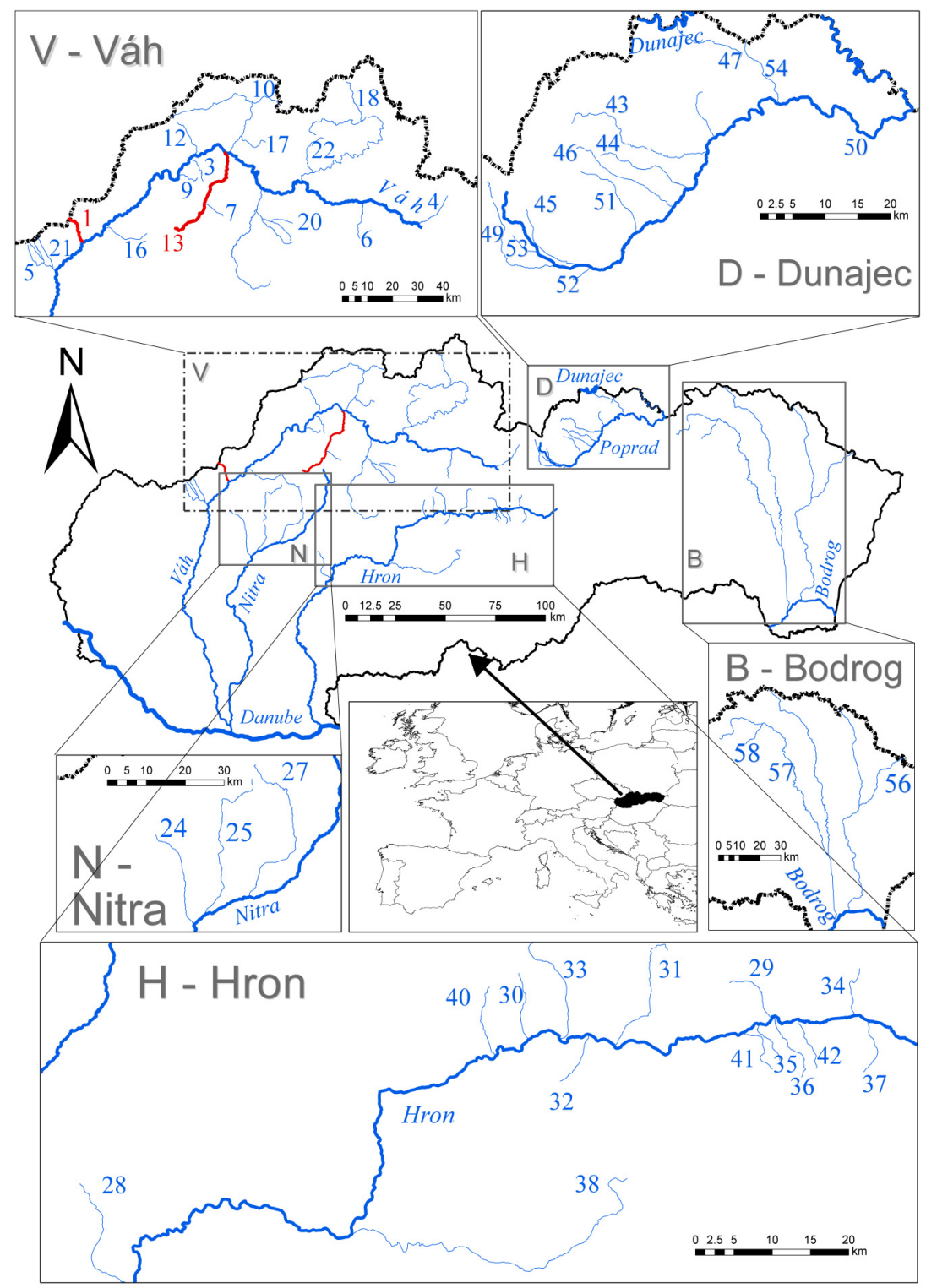

Fig. 1. Mountain and piedmont streams selected in Slovakia.

\section{Topographical measurements of the reference reaches}

The accuracy of the topographical survey of the reaches was adapted to the requirements of the hydraulic modelling. The river channel morphology was measured by cross-sections using levelling (Leica Sprinter 200M automatic level with height accuracy of $1.5 \mathrm{~mm} / 1000 \mathrm{~m}$ ). Cross-sections locations were set by the Leica FlexLine TS02 Total Station (positional accuracy $1.5 \mathrm{~mm}+2 \mathrm{ppm}$ ). Transformation to a national coordinate system S-JTSK was provided by the Leica GS15 GNSS measurements in the permanent SmartNet network.

\section{Evaluation of the probability distribution functions and return period curves in the reference reaches of the streams}

The quality of the habitat was assessed at different flow rates, and the M-day flow rates, determined in cooperation with the Slovak Hydrometeorological Institute, were used in the reference reaches. M-day flow is the average daily flow rate reached or exceeded by $M$ days a year. The evaluation followed the interpolation method outlined in the national standard STN 75 1410-1:2008-01 (2008). The characteristics of the reference reaches and their M-day flows are presented in Table 1 .

\section{RESULTS \\ Generalization of the suitability curves}

Suitability curves are time-consuming to develop because they are derived from an ichthyological survey using an electrical aggregate. If at all possible, therefore HSCs should be generalized.

As previously noted, the adult brown trout is the most sensitive bioindicator; therefore, we have generalized the characteristics of this fish in this study. A more detailed analysis and evaluation of the correlation between the abiotic and biotic characteristics is given in Macura et al. (2012).

The set of curves derived from the reference reaches of the streams (Table 1) was divided into several intervals depending on the average maximum water depths in the reach, i.e., $<0.20 \mathrm{~m}$, $0.21-0.30 \mathrm{~m}, 0.31-0.40 \mathrm{~m}$, and $0.41-0.50 \mathrm{~m}$. The average maximum water depth represents the average value of the maximum depths at the reference reaches. Each water depth interval was assigned to the corresponding HSCs, which were plotted together. 
Influence of discharge on fish habitat suitability curves in mountain watercourses in IFIM methodology

Table 1. The characteristics of the reference reaches.

\begin{tabular}{|c|c|c|c|c|c|c|c|}
\hline \multirow{3}{*}{ Stream } & \multirow{3}{*}{ Catchment } & \multirow{3}{*}{ Stream character } & \multicolumn{4}{|c|}{ M-day flow } & \multirow{2}{*}{ Brown trout abundance } \\
\hline & & & & $Q_{30}$ & $Q_{270}$ & $Q_{364}$ & \\
\hline & & & $\left(\mathrm{km}^{2}\right)$ & $\left(\mathrm{m}^{3} \cdot \mathrm{s}^{-1}\right)$ & $\left(\mathrm{m}^{3} \cdot \mathrm{s}^{-1}\right)$ & $\left(\mathrm{m}^{3} \cdot \mathrm{s}^{-1}\right)$ & $\left(\right.$ pcs.ha $\left.{ }^{-1}\right)$ \\
\hline Drietomica 1 & Váh & Regulated & 90.3 & 2.319 & 0.24 & 0.037 & 109 \\
\hline Drietomica 2 & Váh & Natural & 82.5 & 2.136 & 0.221 & 0.034 & 364 \\
\hline Hradnianka & Váh & Natural & 32.1 & 0.675 & 0.133 & 0.025 & 1081 \\
\hline Hybica 1 & Váh & Natural & 44.8 & 1.108 & 0.239 & 0.03 & 624 \\
\hline Kamečnica & Váh & Natural & 12.8 & 0.366 & 0.038 & 0.006 & 2267 \\
\hline Klačianka & Váh & Natural & 27.2 & 0.76 & 0.137 & 0.02 & 1374 \\
\hline Lesnianka 1 & Váh & Regulated & 25.3 & 1.179 & 0.169 & 0.058 & 1131 \\
\hline Lesnianka 2 & Váh & Natural & 20.9 & 1.052 & 0.151 & 0.052 & 745 \\
\hline Manínsky stream & Váh & Natural & 9.6 & 0.295 & 0.06 & 0.015 & 900 \\
\hline Osčadničanka & Váh & Regulated & 52 & 2.613 & 0.27 & 0.05 & 35 \\
\hline Osčadničanka & Váh & Natural & 52 & 2.613 & 0.27 & 0.05 & 560 \\
\hline Petrovička 2 & Váh & Regulated & 33.5 & 1.414 & 0.126 & 0.016 & 745 \\
\hline Rajčianka 1 & Váh & Natural & 12 & 0.457 & 0.073 & 0.012 & 1326 \\
\hline Rajčianka 2 & Váh & Regul. - old & 11 & 0.457 & 0.073 & 0.012 & 1680 \\
\hline Rajčianka 3 & Váh & Regul. - new & 8.7 & 0.457 & 0.073 & 0.012 & 519 \\
\hline Teplička 2 & Váh & Natural & 51.1 & 1.474 & 0.253 & 0.052 & 288 \\
\hline Vadičovsky stream & Váh & Natural & 39.4 & 1.66 & 0.17 & 0.05 & 318 \\
\hline Veselianka 1 & Váh & Natural & 85.9 & 3.665 & 0.489 & 0.127 & 306 \\
\hline Veselianka 2 & Váh & Natural & 69.1 & 3.274 & 0.381 & 0.104 & 346 \\
\hline Vôdky & Váh & Natural & 15.8 & 0.4 & 0.115 & 0.045 & 1007 \\
\hline Vrzavka & Váh & Natural & 10 & 0.535 & 0.055 & 0.008 & 1802 \\
\hline Zázrivka 1 & Váh & Natural & 76.5 & 4.269 & 0.817 & 0.258 & 325 \\
\hline Zázrivka 2 & Váh & Natural & 96.1 & 5.219 & 0.999 & 0.315 & 216 \\
\hline Chotina & Nitra & Natural & 82 & 1.843 & 0.15 & 0.008 & 242 \\
\hline Bebrava 1 & Nitra & Regulated & 71.2 & 1.939 & 0.376 & 0.124 & 111 \\
\hline Bebrava 2 & Nitra & Natural & 43.4 & 1.819 & 0.353 & 0.116 & 154 \\
\hline Nitrica 1 & Nitra & Regulated & 188.4 & 6.169 & 0.737 & 0.211 & 110 \\
\hline Nitrica 2 & Nitra & Natural & 202.5 & 6.233 & 0.744 & 0.213 & 188 \\
\hline Kl'ak & Hron & Natural & 54.6 & 2.342 & 0.266 & 0.076 & 591 \\
\hline Bacúšsky s. & Hron & Natural & 24.2 & 0.876 & 0.223 & 0.118 & 329 \\
\hline Bukovec & Hron & Natural & 16.8 & 0.785 & 0.126 & 0.065 & 470 \\
\hline Bystrianska & Hron & Natural & 90.9 & 4.927 & 0.802 & 0.35 & 103 \\
\hline Čelno & Hron & Natural & 10 & 0.326 & 0.064 & 0.022 & 1074 \\
\hline Jaseniansky stream & Hron & Natural & 56.9 & 3.463 & 0.702 & 0.21 & 509 \\
\hline Krivul'a & Hron & Natural & 5.1 & 0.421 & 0.074 & 0.035 & 505 \\
\hline Malý Zelený s. & Hron & Natural & 6.5 & 0.212 & 0.047 & 0.02 & 614 \\
\hline Petríkovo & Hron & Natural & 17 & 0.58 & 0.128 & 0.055 & 267 \\
\hline Rácov & Hron & Natural & 19.8 & 0.569 & 0.126 & 0.054 & 932 \\
\hline Slatina 1 & Hron & Regulated & 400.1 & 8.318 & 1.148 & 0.384 & - \\
\hline Slatina 2 & Hron & Natural & 383.4 & 8.047 & 1.11 & 0.372 & - \\
\hline Vážna & Hron & Natural & 15.4 & 0.612 & 0.136 & 0.058 & 298 \\
\hline V. Zelený stream & Hron & Natural & 11.8 & 0.356 & 0.079 & 0.034 & 169 \\
\hline Volchovo & Hron & Natural & 10 & 0.295 & 0.065 & 0.028 & 1003 \\
\hline Biela & Dunajec & Natural & 91.2 & 4.063 & 0.421 & 0.095 & 217 \\
\hline Čierna voda & Dunajec & Natural & 35.5 & 0.598 & 0.113 & 0.021 & 613 \\
\hline Hagánsky stream & Dunajec & Natural & 10.5 & 0.44 & 0.115 & 0.042 & 843 \\
\hline Kežmar. B. Voda & Dunajec & Natural & 27.3 & 0.44 & 0.098 & 0.003 & 938 \\
\hline Lipník 1 & Dunajec & Natural & 76.1 & 2.485 & 0.391 & 0.077 & 441 \\
\hline Lipník 2 & Dunajec & Natural & 37 & 1.491 & 0.235 & 0.046 & 570 \\
\hline Mlynica & Dunajec & Natural & 39.8 & 0.44 & 0.145 & 0.049 & 2939 \\
\hline Poprad & Dunajec & Regulated & 45.7 & 2.81 & 0.566 & 0.188 & 318 \\
\hline Skalnatý stream & Dunajec & Natural & 33.7 & 1.346 & 0.312 & 0.085 & 395 \\
\hline Teplica & Dunajec & Natural & 3.5 & 0.057 & 0.014 & 0.001 & 8824 \\
\hline Vesník & Dunajec & Natural & 4 & 0.06 & 0.018 & 0.004 & 1520 \\
\hline Kamienka 1 & Dunajec & Regulated & 34.4 & 1.01 & 0.116 & 0.006 & 626 \\
\hline Kamienka 2 & Dunajec & Natural & 19.5 & 0.563 & 0.065 & 0.003 & 1376 \\
\hline Udava & Bodrog & Natural & 59.3 & 2.467 & 0.19 & 0.025 & 1456 \\
\hline Topl'a & Bodrog & Natural & 131.5 & 2.288 & 0.443 & 0.129 & 380 \\
\hline Šibská voda & Bodrog & Natural & 54.9 & 0.711 & 0.141 & 0.024 & 5429 \\
\hline
\end{tabular}

The suitability curves for the $21-30 \mathrm{~cm}$ water depth interval are shown in Fig. 2; similarly, the HSCs for all the other depth intervals mentioned above are shown in Fig. 3. These curves were derived from ichthyological measurements during low flows and so they do not represent the state during higher flow rates.
The main result of the study was to develop the HSC modification methodology based on the optimal range of flow velocities for the brown trout.

The preference of the trout habitats in relation to the discharge was examined on the Drietomica River. The results show a good consistency between the HSC derived from an 


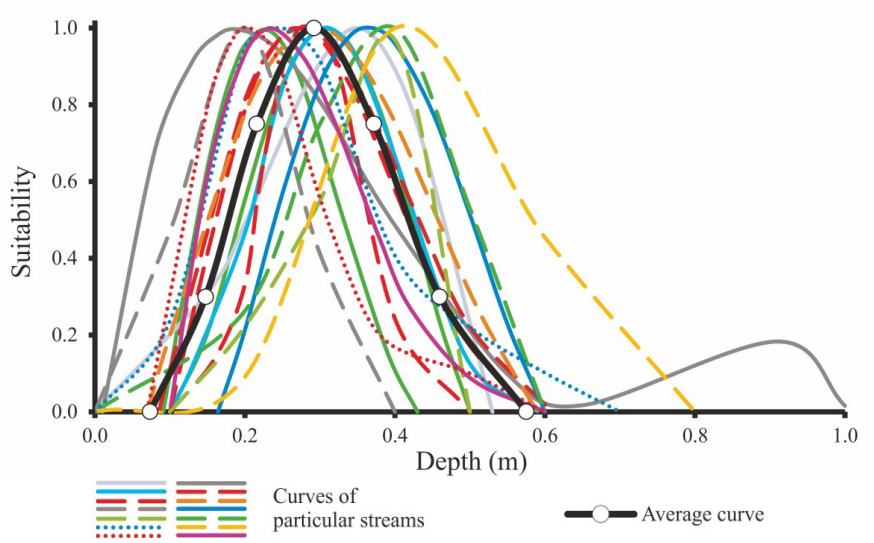

Fig. 2. Representative averaged suitability curves for flows with average water depths from 21 to $30 \mathrm{~cm}$ (solid black line) derived from the set of HSCs obtained by direct measurements of the mountain streams in Slovakia (colour lines).

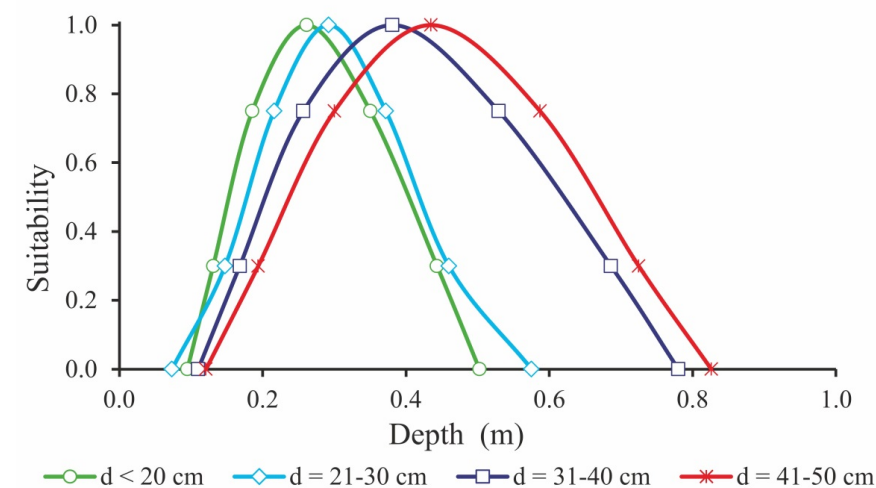

Fig. 3. Average water depth suitability curves for the brown trout (Salmo trutta m. fario) divided into intervals of the mean maximum water depth.

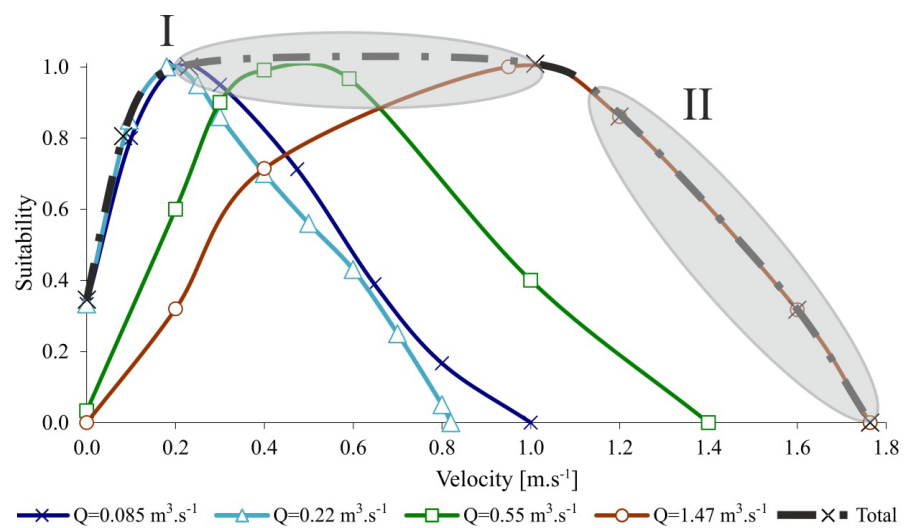

Fig. 4. Generalized suitability curve for the flow velocity for brown trout (Salmo trutta m. fario) in the Drietomica River, areas I. - II.

optimal range of flow velocities and the HSC determined from direct survey at individual flows. An example of the shape of the curves created by both methods is given in Fig. 8 .

\section{Impact of the flow velocity on the habitat quality}

In general, it can be stated that there is a significant reduction of flow velocity in large bed scours, which cause the changes in the character of the substrate, from gravel-sand to silt-clay material. There were only few such bed scours within our reaches. However, there was low trout abundance in all cases.
The second factor that limits the rate of suitability of a habitat is the flow velocity at which the fish are washed away into other habitats. Therefore, a habitat that is suitable at a low flow rate is not necessarily suitable at higher flow rates, and this has a direct influence on the shape of the HSC. The limiting factor is the ability of the fish to resist the flow velocity. Hooper (1973) reported that the most suitable flow velocity for the brown trout was between 0.40 and $0.52 \mathrm{~m} . \mathrm{s}^{-1}$. According to Shirvell and Dungey (1983), the trout mostly prefers flow velocities close to $0.40 \mathrm{~m} \cdot \mathrm{s}^{-1}$. Reiser and Wechse (1976) also identified a range of critical flow velocities for the brown trout. Their minimum flow velocity $\left(v_{\text {min }}\right)$ was below $0.15 \mathrm{~m} . \mathrm{s}^{-1}$, while the maximum flow velocity $\left(v_{\max }\right)$ that the brown trout would resist in preferred microhabitats for a long time was $0.90 \mathrm{~m} . \mathrm{s}^{-1}$. The optimal range of flow velocities for the brown trout was between $0.40 \mathrm{~m} . \mathrm{s}^{-1}$ and $0.70 \mathrm{~m} . \mathrm{s}^{-1}$. Similar velocities were present also in the reference reach of the Drietomica River.

In this study, we assumed a mean velocity in vertical that was determined from three values, i.e., three propellers on a hydrometric rod. A decrease in preference occurred at a velocity of $1.0 \mathrm{~m} . \mathrm{s}^{-1}$ (Fig. 4). This value is consistent with the maximum flow velocity $v_{\max }=0.9 \mathrm{~m} . \mathrm{s}^{-1}$ stated by Reiser and Wechse (1976) that the brown trout would resist in the preferred microhabitats for a long time.

Based on previous statements, we can conclude that the flow rate mainly affects the shape of a HSC during higher flow rates, which leads to washing out the fish from the preferred habitat. We used the HSCs that were determined from the ichthyological survey of the Drietomica River at different flow rates to derive a HSC that characterized the quality of the habitat in a wider flow range, i.e., from the low flow up to the flow at which the fish were washed out from their preferred habitats.

\section{Description of the suitability curve areas for the velocity}

The HSC for the velocity, i.e., the line of the HSC for different flow rates (labelled by different line types and colours), can be divided into different characteristic areas as follows (Fig. 4):

\section{The optimal level of fitness, area I.}

At a low flow rate the brown trout chooses a habitat according to its depth. Fig. 5 shows an evaluation of the rate of suitability of the reference reach of the Drietomica River at the lowest measured flow rate $(Q)$ of $0.085 \mathrm{~m}^{3} . \mathrm{s}^{-1}\left(Q_{355}\right.$ $\left.=0.077 \mathrm{~m}^{3} \cdot \mathrm{s}^{-1}\right)$. The cover areas, where the depths are larger and the velocities are smaller (Fig. 5) have the highest suitability rate. A flow rate of $0.55 \mathrm{~m}^{3} . \mathrm{s}^{-1}\left(Q_{180}=0.43\right.$ $\left.\mathrm{m}^{3} \cdot \mathrm{s}^{-1}\right)$ still corresponds to the optimum conditions for the brown trout; therefore, the habitat quality is the same as for the $Q_{355}$ flow.

\section{Declining rate of suitability, area II.}

When the flow increases, the velocity also increases. When the velocity exceeds the threshold that the brown trout is usually able to resist, the rate of suitability is significantly reduced, and is represented by Region II in Fig. 4. The rate of suitability for the velocity at a flow rate of 1.50 $\mathrm{m}^{3} \cdot \mathrm{s}^{-1}\left(Q_{60}\right)$ is evaluated in Fig. 6. The areas with lower rates of suitability at higher flow rates start to occur in the areas that were the most suitable at lower flow rates. 


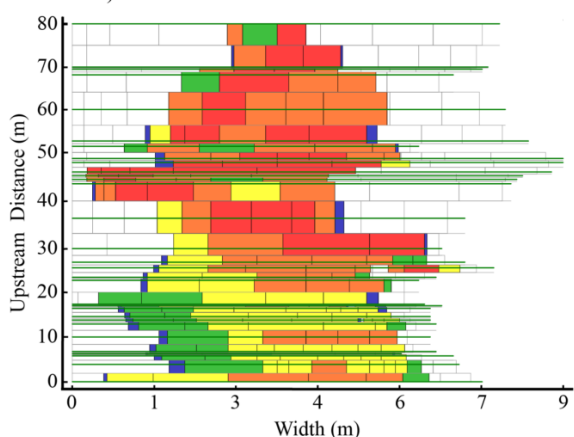

b)

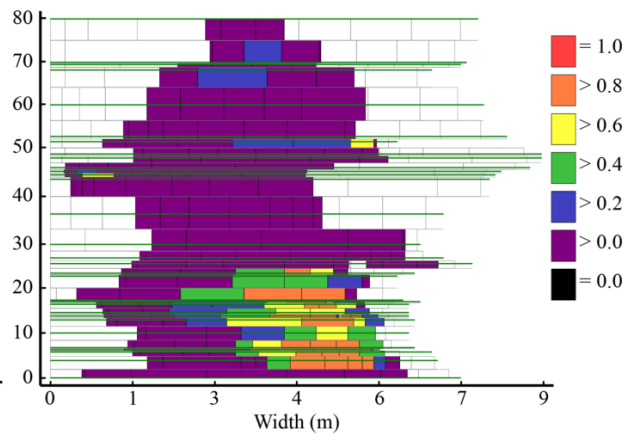

Fig. 5. Plan view of suitability rate of the Drietomica River for the brown trout (Salmo trutta m. fario) for $Q=0.085 \mathrm{~m}^{3} . \mathrm{s}^{-1}$ (a) for the velocity, and (b) for the depth. Width $(\mathrm{m})$ is the channel width in the water level and upstream distance $(\mathrm{m})$ is a relative river station (distance between cross-sections).

a)

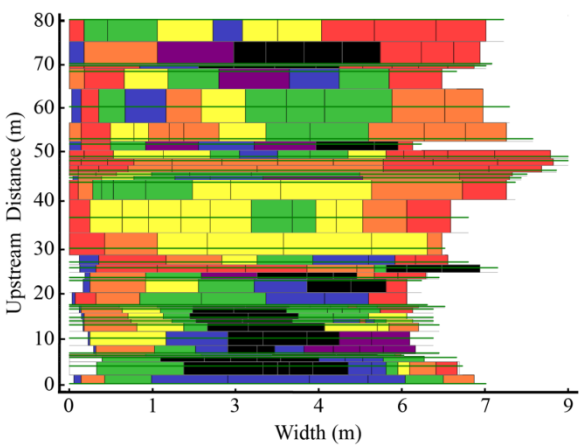

b)

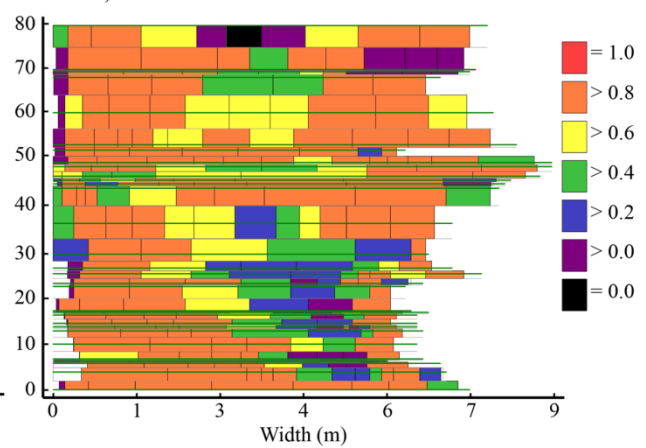

Fig. 6. Plan view of suitability rate of the Drietomica River for the brown trout (Salmo trutta $\mathrm{m}$. fario) for $Q=1.50 \mathrm{~m}^{3} . \mathrm{s}^{-1}$ (a) for the depth, and $(\mathrm{b})$ for the velocity. Width $(\mathrm{m})$ is the channel width in the water level and upstream distance $(\mathrm{m})$ is a relative river station (distance between cross-sections).

Table 2. The results of the ichthyological survey for the Drietomica River in 2012 and 2013. species: CS - Carpathian sculpin (Cottus poecilopus), BT - brown trout (Salmo trutta $\mathrm{m}$. fario), $\mathrm{Ch}$ - chub (Leuciscus cephalus), $\mathrm{M}$ - Eurasian minnow (Phoxinus phoxinus), $\mathrm{S}-$ stone loach (Barbatula barbatula).

\begin{tabular}{|c|c|c|c|c|c|c|c|c|c|c|c|c|c|c|c|c|c|c|c|c|}
\hline & s section & 1 & 2 & 3 & 4 & 5 & 6 & 7 & 8 & 9 & 10 & 11 & 12 & 13 & 14 & 15 & 16 & 17 & 18 & 19 \\
\hline \multirow{6}{*}{$\begin{array}{l}\tilde{u} \\
\frac{\tilde{J}}{0} \\
\tilde{D}\end{array}$} & CS & $1 / 0$ & $3 / 2$ & $2 / 0$ & $10 / 3$ & $0 / 2$ & $0 / 0$ & $3 / 0$ & $1 / 2$ & $2 / 2$ & $0 / 0$ & $0 / 0$ & $0 / 0$ & $2 / 0$ & $5 / 0$ & $0 / 0$ & $3 / 2$ & $2 / 2$ & $1 / 0$ & $1 / 2$ \\
\hline & BT & $1 / 2$ & $3 / 2$ & $4 / 0$ & $0 / 0$ & $2 / 1$ & $5 / 1$ & $2 / 0$ & $2 / 1$ & $4 / 3$ & $1 / 0$ & $3 / 0$ & $2 / 0$ & $1 / 2$ & $4 / 2$ & $9 / 2$ & $1 / 0$ & $2 / 0$ & $2 / 1$ & $1 / 2$ \\
\hline & $\mathrm{Ch}$ & $0 / 0$ & $0 / 0$ & $0 / 0$ & $0 / 0$ & $1 / 0$ & $0 / 0$ & $0 / 0$ & $0 / 0$ & $0 / 0$ & $0 / 0$ & $0 / 0$ & $0 / 0$ & $0 / 0$ & $0 / 0$ & $0 / 0$ & $0 / 0$ & $0 / 0$ & $0 / 0$ & $0 / 0$ \\
\hline & $\mathrm{M}$ & $0 / 0$ & $0 / 0$ & $0 / 0$ & $0 / 0$ & $0 / 0$ & $0 / 11$ & $0 / 0$ & $0 / 0$ & $0 / 0$ & $0 / 0$ & $0 / 0$ & $0 / 0$ & $0 / 0$ & $0 / 2$ & $0 / 0$ & $0 / 0$ & $0 / 0$ & $0 / 0$ & $0 / 0$ \\
\hline & SL & $0 / 0$ & $0 / 0$ & $0 / 0$ & $0 / 0$ & $0 / 0$ & $0 / 0$ & $0 / 0$ & $0 / 0$ & $0 / 0$ & $0 / 0$ & $0 / 0$ & $0 / 0$ & $1 / 0$ & $0 / 0$ & $0 / 0$ & $0 / 0$ & $0 / 0$ & $0 / 0$ & $0 / 0$ \\
\hline & Total & $86 / 50$ & & & & & & & & & & & & & & & & & & \\
\hline
\end{tabular}

Legend for Table 2: $\mathrm{x} / \mathrm{y}-\mathrm{x}$ is the amount of the specific fish species during the measurement on the 8.7.2012

$\mathrm{y}$ is the amount of the specific fish species during the measurement on the 8.7.2013

The ichthyological and hydrometrical measurements on the reference reach of the Drietomica River demonstrate that, at a flow rate of $1.47 \mathrm{~m}^{3} . \mathrm{s}^{-1}$, areas with velocities higher than 1.20 $\mathrm{m} . \mathrm{s}^{-1}$, that the trout cannot permanently resist, were created.

For a flow rate of $1.47 \mathrm{~m}^{3} \cdot \mathrm{s}^{-1}$, the number of brown trout in their preferred areas decreased significantly. In 19 microhabitats, there were 32 adult trout when the flow rate was 0.55 $\mathrm{m}^{3} . \mathrm{s}^{-1}$, but only 15 trout when the flow rate was $1.47 \mathrm{~m}^{3} . \mathrm{s}^{-1}$ (Table 2). The fish started to move into the slower areas (cover places, flow obstacles and the like) for $1.47 \mathrm{~m}^{3} \cdot \mathrm{s}^{-1}$. These results are similar to those from other locations. For example, at locations 6,14 , and 15 , the number of fish decreased from $5 \mathrm{pc}$ to $1 \mathrm{pc}$, from 4 to 2 , and from 9 to 2 , respectively (Table 2). These results also correspond with the previously described literature parameters for the maximum flow velocity $v_{\max }=0.9$ $\mathrm{m} . \mathrm{s}^{-1}$. At a flow velocity of $1.2 \mathrm{~m} . \mathrm{s}^{-1}$, there was a significant decrease in the fish quantity.

\section{Effect of the depth on the quality of an aquatic habitat}

Evaluation of the measurements from 59 representative reaches in 43 mountain streams showed that the depth and hydraulic characteristics of the flow were strongly correlated in natural watercourses (Macura et al., 2012).

Trout prefer habitats with a sufficient depth until higher velocities start to flush the fish out of these habitats. This fact is documented by the set of HSCs that were derived from four measurements during four various flow rates (Fig. 7). The curves have similar shapes and only shift when the depth increased at a higher flow rate. As the depth increases, the suitable habitat area increases as well, and improved quality of the habitat is still maintained. The upper area of the HSC is therefore determined by the shape of the curve at the low flow rate; the rate of suitability is constant and has a maximum value (Fig. 7; bold red dashed line). The course of the HSC for trout or salmon populations at a depth is provided, for example, by 
Booker and Acreman (2007), Mäki-Petäys et al. (2002), or Freeman et al. (1999). A constant maximum suitability rate can be regarded as a hypothetical assumption, because a HSC represents the frequency of the occurrence of fish. In the clean main channel, the velocities are typically higher at higher depths, and the fish are washed out of the preferred areas; this occurred at a flow rate of $1.47 \mathrm{~m}^{3} . \mathrm{s}^{-1}$ in the Drietomica River.

This analysis shows that the suitability of the habitat was limited by the water depth when the flow was low (Fig. 7). At higher flow rates the velocity had a strong influence. At a flow rate of $1.47 \mathrm{~m}^{3} \cdot \mathrm{s}^{-1}$, there was a significant increase in flow velocities, and a decrease of fish abundance in their preferred habitats. This flow rate can therefore be considered marginal, and the declining area of the HSCs for velocity and depth was represented by the HSCs for a flow of 1.47 $\mathrm{m}^{3} . \mathrm{s}^{-1}$ (brown curve in Fig. 7). In Figs. 4 and 7 the suitability curve is shown by a bold dashed black line labelled by crosses that represents the actual habitat preference of brown trout.

In Fig. 7, there are HSCs which were derived from direct measurements at four various water stages. In Fig. 8, the resulting curve from Fig. 7 is compared with a curve that was derived from the generalized HSC in Fig. 3. The Drietomica River belongs to the depth category $d=0.41-50$ $\mathrm{cm}$ (marked with a red line). In the Drietomica hydraulic model, a flow rate, at which the average velocity at maximum depths reached $0.9 \mathrm{~m} . \mathrm{s}^{-1}$, was determined. This value was reached at a flow rate of $1.25 \mathrm{~m}^{3} . \mathrm{s}^{-1}$ and the mean water level difference compared to the one at $Q_{365}$ was 24 $\mathrm{cm}$. The peak of the curve was moved by this value $(24$ $\mathrm{cm}$ ), as shown in Fig. 8. Comparing both curves, it can be concluded that there is a good match between the two.

The HSCs plotted for the velocity (Fig. 4) and depth (Fig. 7) indicated that changes in habitat preference followed the same trends as changes in the water surface. Specifically, the shelter depths ranged from $0.15 \mathrm{~m}\left(d_{\text {min }}\right)$ to $0.60 \mathrm{~m}\left(d_{\max }\right)$ at a flow rate of $Q=0.085 \mathrm{~m}^{3} \cdot \mathrm{s}^{-1}$, and the maximum fitness was at a depth of $0.5 \mathrm{~m}$ (Fig. 7; dark blue curve labelled by crosses). At the highest measured flow rate $\left(Q=1.47 \mathrm{~m}^{3} \cdot \mathrm{s}^{-1}\right)$, the shelter depths ranged from 0.45 $\mathrm{m}\left(d_{\min }\right)$ to $0.88 \mathrm{~m}\left(d_{\max }\right)$. The longitudinal profiles show that the water level varied from 0.2 to $0.3 \mathrm{~m}$ for flow rates of $0.085 \mathrm{~m}^{3} . \mathrm{s}^{-1}$ and $1.47 \mathrm{~m}^{3} \cdot \mathrm{s}^{-1}$ in the various cross sections. According to Table 3 , the difference of $d_{\max }$ was $28 \mathrm{~cm}$. The changes in the water surface level and in the maximum rate of suitability were therefore practically identical in this case. Similar results have been obtained when the changes in suitability for velocity were compared at flow rates of $0.085 \mathrm{~m}^{3} . \mathrm{s}^{-1}$ and $1.47 \mathrm{~m}^{3} \cdot \mathrm{s}^{-1}$. The difference in $v_{\max }$ for these two flow rates was $0.51 \mathrm{~m} . \mathrm{s}^{-1}$ (Table 3).

From previous statements, it follows that the shape of the HSC at the low flow determines the upward part of the HSC. It is not necessary to derive the downward part of the HSC from direct measurements as presented on the example of Drietomica. This part can be constructed by moving a curve to an area where the fish would resist the higher velocities in the shelter for a longer time. Specifically, in Drietomica that occurs for a flow of $1.47 \mathrm{~m}^{3} . \mathrm{s}^{-1}$, with maximum velocities of $0.95 \mathrm{~m} . \mathrm{s}^{-1}$ (Tab. 3). The water level difference between flows 0.085 and $1.47 \mathrm{~m}^{3} \cdot \mathrm{s}^{-1}$ was $43 \mathrm{~cm}$ $\left(d_{\max }-d_{\min }\right.$ from Tab. 3$)$. The HSC can be shifted by this value from a low flow. The shape of the HSC thus constructed is similar to the curve resulting from the direct measurements in Fig. 7. This technique can be universally applied including use of the generalized HSCs in Fig. 3.

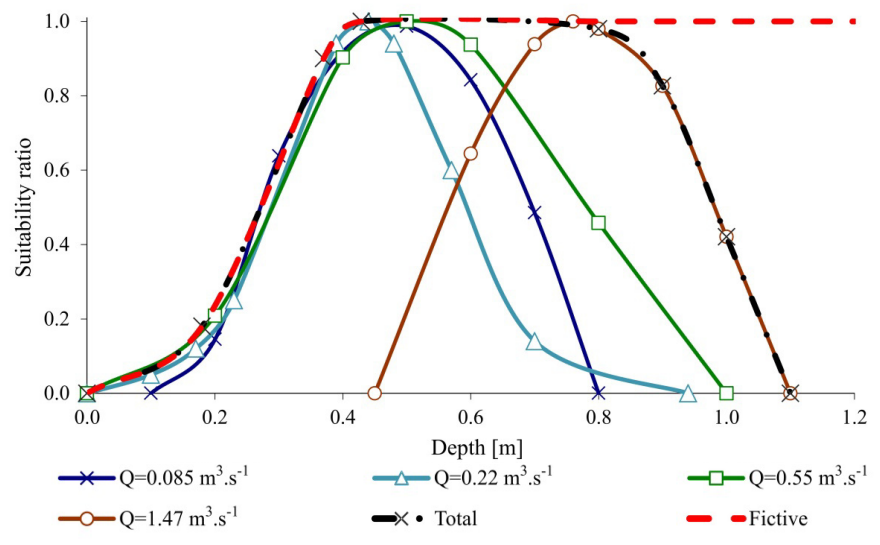

Fig. 7. Depth suitability curves for the brown trout at Drietomica River derived for $Q=0.085,0.22,0.55$, and $1.47 \mathrm{~m}^{3} \cdot \mathrm{s}^{-1}$.

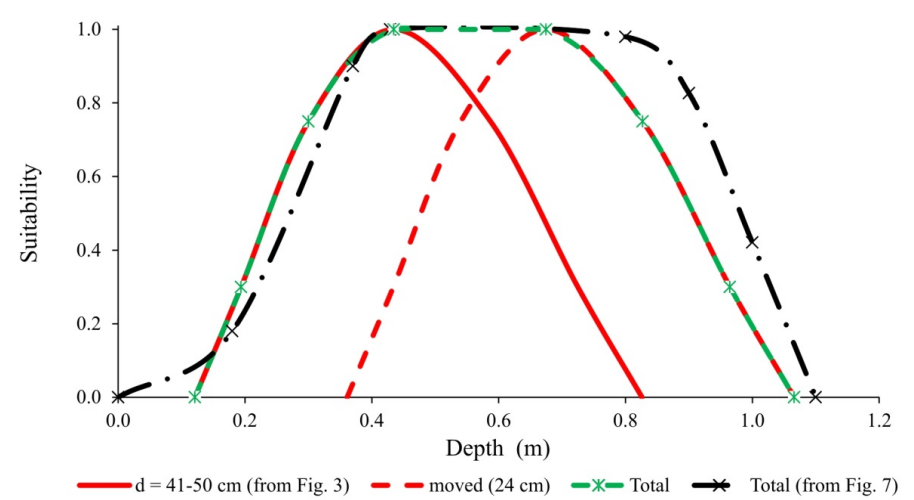

Fig. 8. Comparison of depth suitability curves for the brown trout at Drietomica River determined by field survey (from Fig. 7) and derived from average curve (from Fig. 3).

Table 3. Comparison of the depth and velocity range in the cover places.

\begin{tabular}{lllllll}
\hline & $\begin{array}{l}d_{\text {avg. }} \\
(\mathrm{m})\end{array}$ & $\begin{array}{l}d_{\min .} \\
(\mathrm{m})\end{array}$ & $\begin{array}{l}d_{\max .} \\
(\mathrm{m})\end{array}$ & $\begin{array}{l}v_{\text {avg. }} \\
\left(\mathrm{m} . \mathrm{s}^{-1}\right)\end{array}$ & $\begin{array}{l}v_{\min .} \\
\left(\mathrm{m} . \mathrm{s}^{-1}\right)\end{array}$ & $\begin{array}{l}v_{\max .} \\
\left(\mathrm{m} . \mathrm{s}^{-1}\right)\end{array}$ \\
\hline$Q=0.085 \mathrm{~m}^{3} \cdot \mathrm{s}^{-1}$ & 0.38 & 0.15 & 0.6 & 0.15 & 0.05 & 0.44 \\
$Q=1.47 \mathrm{~m}^{3} \cdot \mathrm{s}^{-1}$ & 0.67 & 0.45 & 0.88 & 0.65 & 0.45 & 0.95 \\
\hline
\end{tabular}

\section{DISCUSSION}

The essential parameters of an instream habitat are divided into abiotic and biotic within IFIM. Data for the abiotic parameters are needed to support the hydraulic flow modelling of the area of interest. Fish, as elements of biotic quality, are bioindicators of a stream habitat. The relationship between the abiotic and biotic characteristics is represented by the HSCs of the individual species, as previously described by Macura et al. (2012). IFIM mostly uses the depth and velocity suitability curves, because they are important characteristics of a mesohabitat (Cluer and Thorne, 2014; Harby et al., 2007; Vezza et al., 2012).

Wilding et al. (2014) noted that, for several years, ecohydraulics research focused on the effects of velocity and depth on the channel habitats of fish and other aquatic species. Applications of numerous models such as IFIM have demonstrated that a stream can provide a range of velocity-depth combinations that support a wide range of species throughout their life stages (Shirvell and Dungey, 1983; Slavík et al., 2005). Previous studies have confirmed the correlation between the suitability curves characteristics and flow hydraulics, especially in relation to water depth and velocity (Davey 
et al., 2011; Macura et al., 2012). Therefore,the study is focused on the transformation of the HSCs for depth. The idea of transforming the HSCs is not new. In the studies of Ayllón et al. (2012) or Valentin et al. (1996) the authors point out that the HSC derived from one flow does not represent the behaviour of the ichthyofauna in the broader flow range. Therefore, they proposed a simple HSC transformation. The top of the curve continues by line with the maximum rate of suitability. This means that any higher flow rate has the maximum suitability rate. On the contrary, the method of the HSC creation introduced in this study describes the real behaviour of ichthyofauna in the whole flow spectrum.

The influence of HSCs on the evaluation of WUA is shown on the example of the Slatina River. For practical purposes, it is very difficult to determine the shape of a HSC using a set of measurements from different flow rates, as has been demonstrated by the example of the Drietomica River. It is advisable to use a technique to modify the HSC derived from the low flow that has been described on the example of Drietomica at the end of the previous chapter. We provide an example from the reference reach of the Slatina River to show how the HSCs for velocity and depth can be modified. The Slatina River is located in central Slovakia and belongs to the Hron River basin; i.e., the left tributary of the Danube River in the Slovak Republic. The Slatina River is surrounded by foothills and is one of the last remaining naturally meandering streams in Slovakia; together with its river bank vegetation, it represents a biocorridor of regional significance.

Table 4. Fish species and amount of fish caught in the $351 \mathrm{~m}$ reference reach of the Slatina River (area of the village of Slatinka).

\begin{tabular}{lc}
\hline Name of species & number \\
\hline Roach (Rutilus rutilus) & 178 \\
Gudgeon (Gobio gobio) & 166 \\
Schneider (Alburnoides bipunctatus) & 139 \\
Chub (Leuciscus cephalus) & 77 \\
Freshwater bream (Abramis brama) & 44 \\
Stone loach (Barbatula barbatula) & 19 \\
Common nase (Chondrostoma nasus) & 17 \\
Common dace (Leuciscus leuciscus) & 11 \\
European perch (Perca fluviatilis) & 7 \\
Eurasian minnow (Phoxinus phoxinus) & 7 \\
Barbel (Barbus barbus) & 4 \\
Grayling (Thymallus thymallus) & 3 \\
Peloponnese barbel (Barbus peloponnesius) & 2 \\
\hline Total & $\mathbf{6 7 4}$ \\
\hline
\end{tabular}

Table 5. Fish species and amount of fish caught in the $377 \mathrm{~m}$ reference reach of the Slatina River (below the village of Zvolenská Slatina).

\begin{tabular}{lc}
\hline Name of species & number \\
\hline Gudgeon (Gobio gobio) & 419 \\
Stone loach (Barbatula barbatula) & 154 \\
Schneider (Alburnoides bipunctatus) & 145 \\
Roach (Rutilus rutilus) & 116 \\
Chub (Leuciscus cephalus) & 92 \\
Bleak (alburnus alburnus) & 15 \\
Freshwater bream (Abramis brama) & 14 \\
Eurasian minnow (Phoxinus phoxinus) & 12 \\
Common dace (Leuciscus leuciscus) & 11 \\
Brown trout (Salmo trutta m. fario) & 9 \\
Common nase (Chondrostoma nasus) & 3 \\
European perch (Perca fluviatilis) & 2 \\
Barbel (Barbus barbus) & 1 \\
Grayling (Thymallus thymallus) & 1 \\
\hline Total & $\mathbf{9 9 4}$ \\
\hline
\end{tabular}

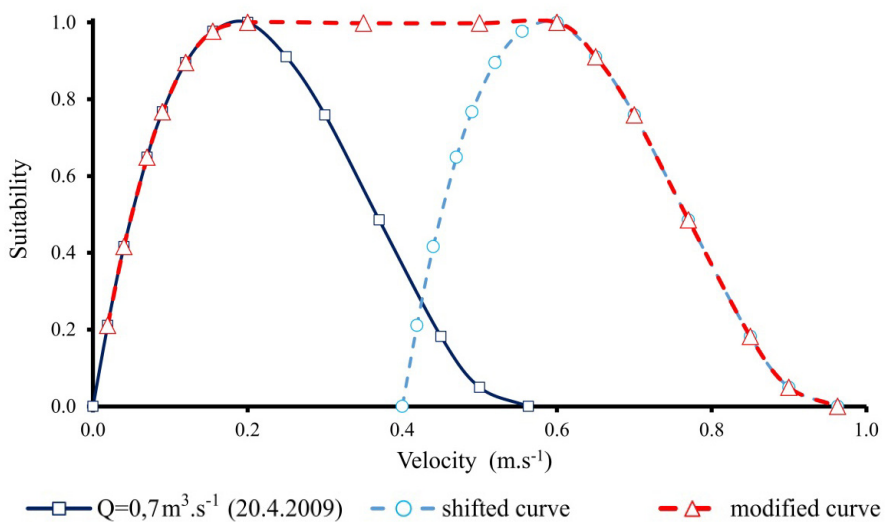

Fig. 9. Derivation of the brown trout velocity suitability curve from the values obtained for $Q=0.7 \mathrm{~m}^{3} \mathrm{~s}^{-1}$, for the Slatina River.

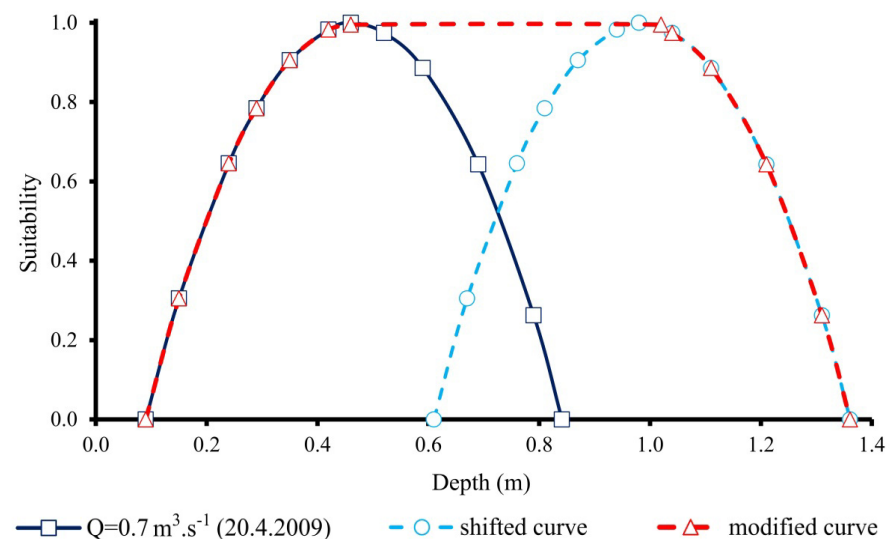

Fig. 10. Derivation of the brown trout depth suitability curve from the values obtained for $Q=0.7 \mathrm{~m}^{3} \mathrm{~s}^{-1}$, for the Slatina River.

Two reference reaches with lengths of 351 and $377 \mathrm{~m}$ were selected in the Slatina River. These reaches were characterized by 21 and 15 cross sections, respectively, which are an essential input for the hydraulic model of the reach. The M-day flows for the area of the reference reaches are provided in Table 1.

An ichthyological survey was carried out in 2012. A total of 674 fish were caught in the 351-m reference reach, and 994 fish were caught in the 377-m reference reach (Tab. 4 and 5).

We used the chub to evaluate the impact of the flow rate and channel morphology, because, out of all the fish that are sensitive to the morphology of a riverbed, the chub was the most abundant. The HSCs for velocity and depth were derived from the ichthyological survey (Figs. 9 and 10). The measurements were taken at a flow rate of $0.643 \mathrm{~m}^{3} \cdot \mathrm{s}^{-1}$, which is about $Q_{330}$ (Table 1). The habitat for the maximum preferences of the chub is at a velocity of 0.20 m.s ${ }^{-1}$ (Fig. 9). However, the chub can withstand a velocity of 0.60 $\mathrm{m} . \mathrm{s}^{-1}$ for an extended period, so the peak of the HSC for the velocity moved to an area of $0.60 \mathrm{~m} . \mathrm{s}^{-1}$ (Fig. 9). The hydraulic model shows that this velocity occurred at a rate of $8.10 \mathrm{~m}^{3} . \mathrm{s}^{-1}$ in the maximum depths where the chub was hiding. The average mean velocity in vertical in the covers at this flow rate was $0.64 \mathrm{~m} . \mathrm{s}^{-1}$. An increase in the flow rate from 0.643 to $8.10 \mathrm{~m}^{3} . \mathrm{s}^{-1}$ resulted in an increase of $0.57 \mathrm{~m}$ in the average water level in the individual cross sections. The HSC for the depth was shifted with this value (Fig. 10). The resulting line from these curves represents the actual shape of the HSC that can be applied to the low flow rates as well as to flow rates of up to $8.0 \mathrm{~m}^{3} \cdot \mathrm{s}^{-1}$, which spans a range from $Q_{365}$ to $Q_{30}$. 


\section{Evaluation of the weighted usable area (WUA)}

This section comprises a documentation and evaluation of the differences in the WUA of a curve derived from a single measurement and of a curve modified for a velocity that the chub can resist for a longer time. Fig. 11 compares the course of the WUA that was derived from the HSC at a low flow rate (dark blue line) and the course of the WUA that was derived from the modified curve shown in Figs. 9 and 10 (in Fig. 11, the line is indicated by a light blue colour). The initial course of the WUA was the same for both methods. The WUA derived from the curve at the low flow rate started to decline at a rate of $1.40 \mathrm{~m}^{3} . \mathrm{s}^{-1}$ (Fig. 11). This trend is apparent from the shape of the HSCs at a flow rate of $0.70 \mathrm{~m}^{3} . \mathrm{s}^{-1}$ (Figs. 9 and 10). The course of the WUA derived from the modified curve has a real shape. The value of the WUA increased until the flow rate reached a value of $4.20 \mathrm{~m}^{3} \cdot \mathrm{s}^{-1}$. The WUA decreased slightly when the flow rate increased further (Fig. 11). The shape of the decreasing part of the WUA curve was not as significant as that of the HSC, because, by increasing the flow rate, the water surface area also increases. In particular, the rate of suitability in the areas with low depths increased when the flow rates were low, meaning that the rate of suitability was small.

When we evaluated the quality of the habitat in the individual cells in the footprint, an even more significant difference was apparent. The quality of the habitat based on the HSC derived at the low flow rate (Figs. 9 and 10 at $Q=$ $\left.0.70 \mathrm{~m}^{3} \cdot \mathrm{s}^{-1}\right)$ is evaluated in Fig. 12. At a flow rate of 8.10 $\mathrm{m}^{3} \cdot \mathrm{s}^{-1}\left(Q_{30}\right)$, the rate of suitability was favourable for the depth, which is logical, because the depth in the shallow

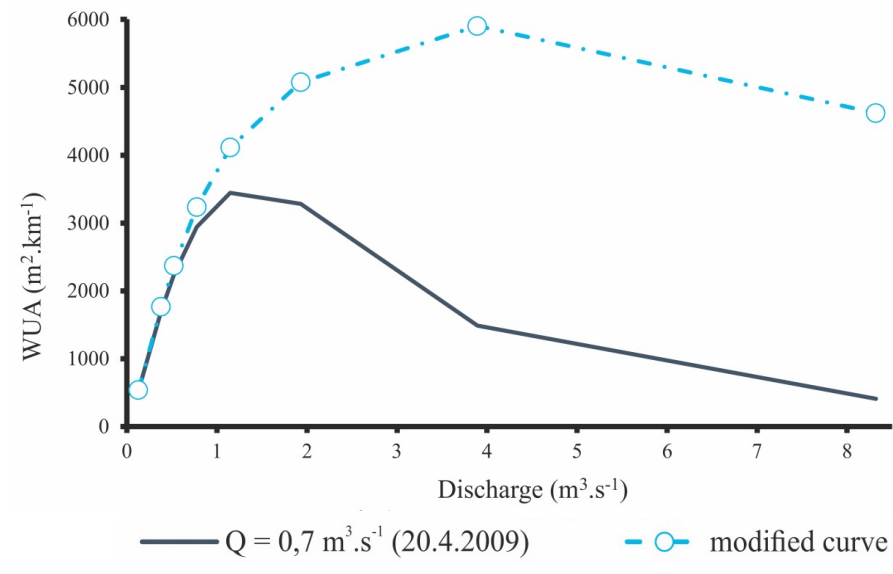

Fig. 11. Comparison of the WUA on the Slatina River. The light blue line was derived from the modified HSCs in Figs. 9 and 10. The dark blue line was derived from the HSC measured at the low flow rate.

areas increases when the flow rate increases (Fig. 12 a). This means that the conditions for the rheophilous species (Brown trout, European grayling) improve when the flow is increased (Harby et al., 2007). A different outcome occurs when the rate of suitability is examined according to the velocity. A significant part of the reach had a higher velocity than the range of the HSCs derived from the minimum flow rate. Therefore, a significant part had zero rate of suitability (Fig. 12 b); moreover, the combined rate of suitability was inappropriate (Fig. $12 \mathrm{c}$ ), as confirmed by the low value of the WUA $\left(500 \mathrm{~m}^{2}\right)$ (Fig. 11).
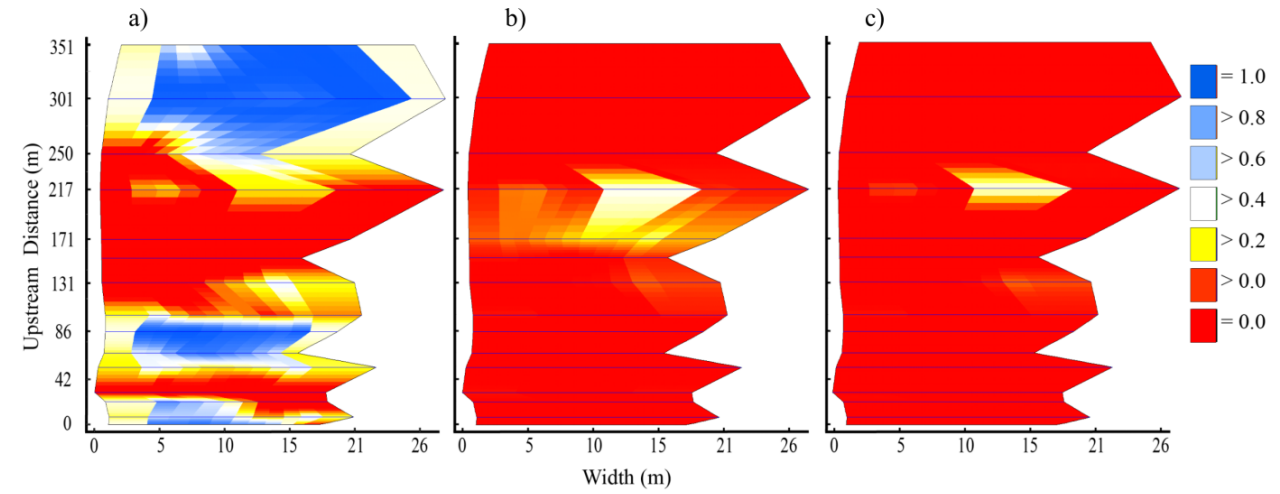

Fig. 12. Rate of suitability for the chub in the Slatina River at a flow rate of $Q_{30}=8.10 \mathrm{~m}^{3} . \mathrm{s}^{-1}$. A HSC modified according to the low flow rates was used. (a) the rate of suitability according to depth, (b) the rate of suitability according to velocity, (c) the combined rate of suitability.

a)

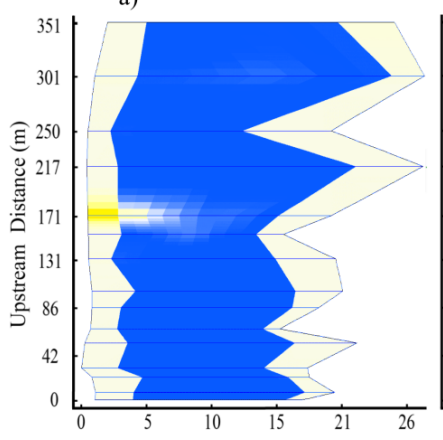

b)

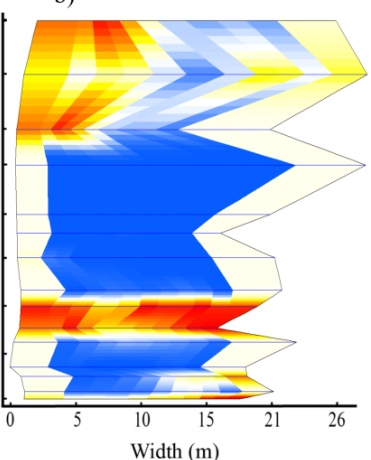

c)

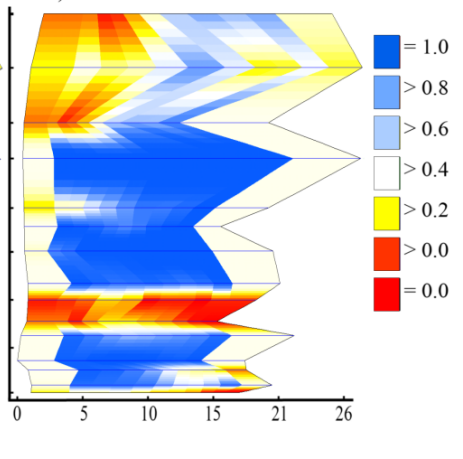

Fig. 13. Rate of suitability for the chub in the Slatina River at a flow rate of $Q_{30}=8.10 \mathrm{~m}^{3} \cdot \mathrm{s}^{-1}$. A HSC modified for a wider range of flow rates was used; (a) the rate of suitability according to depth, (b) the rate of suitability according to velocity, (c) combined rate of suitability. 
The same reach was evaluated with modified HSCs (Figs. 9 and 10). Fig. 13 shows that a substantial part of the reach had the highest quality level. This is the actual condition, because the velocities and depths of the flow provide an optimal area for the ichthyofauna. It can be stated that HSCs derived from a particular measurement can be applied only for the discharge at which they were derived. The tests show that the modified HSC represented fish behaviour across a wider flow range.

Acknowledgements. We thank staff from the Slovak Hydrometeorological Institute for cooperation on the M-day flow rates determination and Jaroslav Andreji from Slovak University of Agriculture in Nitra for cooperation on the ichthyological surveys. This study has been supported by the Scientific Grant Agency under Contracts Nos. VEGA 1/0625/15 and VEGA $1 / 0665 / 15$.

\section{REFERENCES}

Aparicio, E., Carmona-Catot, G., Moyle, P.B., García-Berthou, E., 2011. Development and evaluation of a fish-based index to assess biological integrity of Mediterranean streams. Aquatic Conserv: Mar. Freshw. Ecosyst., 21, 324-337, DOI: 10.1002/aqc.1197.

Artemiadou, V., Lazaridou, M., 2005. Evaluation score and interpretation index for the ecological quality of running waters in Central and Northern Hellas. Environ. Monit. Assess., 110, 1-40. DOI: 10.1007/s10661-005-6289-7.

Ayllón, D., Almodóvar, A., Nicola, G.G., Elvira, B., 2009. Interactive effects of cover and hydraulics on brown trout habitat selection patterns. River Res. Applic., 25, 10511065. DOI: 10.1002/rra.1215.

Ayllón, D., Almodóvar, A., Nicola, G.G., Elvira, B., 2010. Modelling brown trout spatial requirements through physical habitat simulations. River Res. Applic., 26, 1090-1102. DOI: $10.1002 /$ rra. 1315 .

Ayllón, D., Almodóvar, A., Nicola, G.G., Elvira, B., 2012. The influence of variable habitat suitability criteria on PHABSIM habitat index results. River Res. Applic., 28, 1179-1188. DOI: 10.1002/rra.1496.

Booker, D.J., Acreman, M.C., 2007. Generalisation of physical habitat-discharge relationships. Hydrol. Earth Syst. Sci., 11, 141-157. DOI: 0.5194/hess-11-141-2007, 2007.

Casper, A. F., Dixon, B., Earls, J., Gore, J. A., 2011. Linking a spatially explicit watershed model (SWAT) with an instream fish habitat model (PHABSIM): A case study of setting minimum flows and levels in a low gradient, subtropical river. River Res. Applic., 27, 269-282. DOI: 10.1002/rra.1355.

Cianfrani, C.M., Sullivan, S.M.P, Hession, W.C, Watzin, M.C., 2009. Mixed stream channel morphologies: implications for fish community diversity. Aquatic Conservation: Marine and Freshwater Ecosystems, 19, 147-156.

Cluer, B., Thorne, C., 2014. A stream evolution model integrating habitat and ecosystem benefits. River Res. Applic., 30, 135-154. DOI: 10.1002/rra.2631.

Davey, A.J.H., Booker, D.J., Kelly, D.J., 2011. Diel variation in stream fish habitat suitability criteria: implications for instream flow assessment. Aquatic Conserv: Mar. Freshw. Ecosyst., 21, 132-145. DOI: 10.1002/aqc.1166.

Döll, P., Zhang, J., 2010. Impact of climate change on freshwater ecosystems: a global-scale analysis of ecologically relevant river flow alterations. Hydrol. Earth Syst. Sci., 14, 783799. DOI: 10.5194/hess-14-783-2010.
Džubáková, K., Molnar, P., Schindler, K., Trizna, M., 2015. Monitoring of riparian vegetation response to flood disturbances using terrestrial photography. Hydrol. Earth Syst. Sci., 19, 195-208. DOI: 10.5194/hess-19-195-2015.

Filipe, A.F., Markovic, D., Pletterbauer, F., Tisseuil, C., De Wever, A., Schmutz, S., Bonada, N., Freyhof, J., 2013. Forecasting fish distribution along stream networks: brown trout (Salmo trutta) in Europe. Diversity Distrib., 19, 10591071. DOI: 10.1111/ddi.12086.

Freeman, M.C., Bowen, Z.H., Bovee, K.D., 1999. Transferability of habitat suitability criteria: response to comment. North American Journal of Fisheries Management, 19, 626-628, DOI: 10.1577/1548-8675(1999)019<0626:TOHSCR $>$.

Friberg, N., Baartrup-Pedersen, A., Pedersen, M.L., Skriver, J., 2005. The new Danish stream monitoring programme (NOVANA) - preparing monitoring activities for the Water Framework Directive era. Environ. Monit. Assess., 111, 2742. DOI: 10.1007/s10661-005-8038-3.

Fung, F., Watts, G., Lopez, A., Orr, H.G., New, M., Extence, C., 2013. Using large climate ensembles to plan for the hydrological impact of climate change in the freshwater environment. Water Resour. Manage., 27, 1063-1084. DOI: 10.1007/s11269-012-0080-7.

Harby, A., Olivier, J.-M., Merigoux, S., Malet, E., 2007. A mesohabitat method used to assess minimum flow changes and impacts on the invertebrate and fish fauna in the Rhône River, France. River Res. Applic., 23, 525-543, DOI: 10.1002/rra.997.

Hatten, J.R., Batt, T.R., Scoppettone, G.G., Dixon, C.J., 2013. An ecohydraulic model to identify and monitor moapa dace habitat. PLoS ONE, 8: e55551. DOI: 10.1371/journal.pone.0055551.

Holčík, J., Macura, V., 2001. Some problems with the interpretation of the impact of stream regulations upon the fish communities. Ecology, 20, 423-434.

Hooper, D., 1973. Evaluation of the effects of flows on trout stream ecology. Pacific Gas and Electric Company, Dept. of Engineering Research, Emeryville, California, 97 p.

Kändler, M., Seidler, C., 2013. Influence of hydrological situations on benthic organisms in a small river in Saxony (Germany). J. Hydrol. Hydromech., 61, 188-194. DOI: 10.2478/johh-2013-0024.

Krysanova, V., Dickens, C., Timmerman, J., Varela-Ortega, C., Schlüter, M., Roest, K., Huntjens, P., Jaspers, F., Buiteveld, H., Moreno, E., de Pedraza Carrera, J., Slámová, R., Martínková, M., Blanco, I., Esteve, P., Pringle, K., Pahl-Wostl, C., Kabat, P., 2010. Cross-comparison of climate change adaptation strategies across large river basins in Europe, Africa and Asia. Water Resour. Manage., 24, 4121-4160. DOI: 10.1007/s11269-010-9650-8.

Lamouroux, N., Capra, H., Pouilly, M., 1998. Predicting habitat suitability for lotic fish: linking statistical hydraulic models with multivariate habitat use models. Regul. Rivers: Res. Mgmt., 14, 1-11, DOI: 10.1002/(SICI)10991646(199801/02)14:1<1::AID-RRR472>3.0.CO;2-D.

Lamouroux, N., Oliver, J.M., Capra, H., Zylberblat, M., Chandesris, A., Roger, P., 2006. Fish community change after minimum flow increase: testing quantitative predictions in the Rhône River at Pierre-Bénite, France. Freshwater Biology, $\quad 51, \quad 1730-1743$, DOI: $10.1111 / \mathrm{j} .1365-$ 2427.2006.01602.x.

Lichner, L.U., Cerdà, A., Rajkai, K., Tesař, M., 2014. Biohydrology research after Landau 2013 conference. J. Hydrol. Hydromech., 62, 253-257. DOI: 10.2478/johh-2014-0041. 
Macura, V., Škrinár, A., Kalúz, K., Jalčovíková, M., Škrovinová, M., 2012. Influence of the morphological and hydraulic characteristics of mountain streams on fish habitat suitability curves. River Res. Applic., 28, 1161-1178. DOI: 10.1002/rra.1518.

Macura, V., Štefunková, Z., Škrinár, A., 2016. Determination of the effect of water depth and flow velocity on the quality of an in-stream habitat in terms of climate change. Advances in Meteorology, Article ID 4560378, 17 p. DOI: $10.1155 / 2016 / 456037$.

Mäki-Petäys, A., Huusko, A., Erkinaro, J., Muotka, T., 2002. Transferability of habitat suitability criteria of juvenile Atlantic salmon (Salmo salar). Canadian Journal of Fisheries and Aquatic Sciences, 59, 2, 218-228. DOI: 10.1139/F01-209.

Mérigoux, S., Lamouroux, N., Olivier, J.-M., Dolédec, S., 2009. Invertebrate hydraulic preferences and predicted impacts of changes in discharge in a large river. Freshwater Biology, 54, 1343-1356, DOI: $10.1111 /$ j.13652427.2008.02160.x.

Palmer, M.A., Menninger, H.L., Bernhardt, E., 2010. River restoration, habitat heterogeneity and biodiversity: a failure of theory or practice? Freshwater Biology, 55, 205-222.

Parasiewicz, P., Walker, J.D., 2007. Comparison of MesoHABSIM with two microhabitat models (PHABSIM and HARPHA). River Res. Applic., 23, 904-923. DOI: 10.1002/rra.1043.

Parra, I., Almodóvar, A., Ayllón, D., Nicola, G.G., Elvira, B., 2011. Ontogenetic variation in density-dependent growth of brown trout through habitat competition. Freshwater Biology, 56, 530-540. DOI: 10.1111/j.1365-2427.2010.02520.x.

Pastuchová, Z., Grešková, A., Lehotský, M., 2010. Spatial distribution pattern of macroinvertebrates in relation to morphohydraulic habitat structure: perspectives for ecological stream assessment. Polish Journal of Ecology, 58, 347-360.

Pekárik, L., Koščo, J., Švátora, M., 2012. Reference conditions for fish microhabitat use in foothill streams: A case study on undisrupted carpathian streams. River Res. Applic., 28, 369 376. DOI: $10.1002 /$ rra. 1462.

Reiser, D.W., Wesche, T.A., 1976. Determination of physical and hydraulic preferences of brown and brook trout in the selection of spawning locations. University of Wyoming, Water Resources Research Institute, Water Resources Series 64, $224 \mathrm{p}$.

Scholten, M., 2003. Efficiency of point abundance sampling by electro-fishing modified for short fishes. Journal of Applied Ichthyology, 19, 265-277, DOI: 10.1046/j.14390426.2003.00505.x.
Shirvell, C.S., Dungey, R.G., 1983. Microhabitats chosen by brown trout for feeding and spawning in rivers. Transactions of the American Fisheries Society, 112, 3, 355-367.

Slavík, O., Bartoš, L., Mattas, D., 2005. Does stream morphology predict the home range size in burbot? Environ. Biol. Fish., 74, 89-98. DOI: 10.1007/s10641-005-3998-2.

Snelder, T.H., Lamouroux, N., 2010. Co-variation of fish assemblages, flow regimes and other habitat factors in French rivers. Freshwater Biology. 55, 881-892. DOI: 10.1111/j.1365-2427.2009.02320.x.

Sullivan, S.M.P., Watzin, M.C., Hession, W.C., 2006. Influence of stream geomorphic condition on fish communities in Vermont, U.S.A. Freshwater Biology, 51, 1811-1826. DOI: 10.1111/j.1365-2427.2006.01616.x.

Valentin, S., Lauters, F., Sabaton, C., Breil, P., Souchon, Y., 1996. Modelling temporal variations of physical habitat for brown trout (Salmo trutta) in hydropeaking conditions. Regulated Rivers: Research \& Management, 12, 2-3, 317-330.

Van Loon, A.F., Ploum, S.W., Parajka, J., Kleig, A.K., Garnier, E., Laaha, G., Van Lanen, H.A.J., 2015. Hydrological drought types in cold climates: quantitative analysis of causing factors and qualitative survey of impacts. Hydrology and Earth System Sciences, 19, 1993-2016. DOI: 10.5194/hess19-1993-2015.

Vezza, P., Parasiewicz, P., Rosso, M., Comoglio, C., 2012. Defining minimum environmental flows at regional scale: Application of mesoscale habitat models and catchments classification. River Res. Applic., 28, 717-730, DOI: 10.1002/rra.1571.

Wilding, T.K., Bledsoe, B., Poff, N.L., Sanderson, J., 2014. Predicting habitat response to flow using generalized habitat models for trout in Rocky Mountain streams. River Res. Applic., 30, 805-824. DOI: 10.1002/rra.2678.

\section{Standards and directives}

Slovak national standard STN 75 1410-1:2008-01, 2008. Hydrology (In Slovak: Hydrológia).

European Union, 2000. Directive 2000/60/EC of the European Parliament and of the Council of 23 October 2000 establishing a framework for Community action in the field of water policy.

Received 17 February 2017 Accepted 17 July 2017 